\title{
MODEL PEMBELAJARAN SCRAMBLE MENGGUNAKAN MEDIA WAYANG PAHLAWAN UNTUK MENINGKATKAN HASIL BELAJAR IPS PESERTA DIDIK KELAS V-A SDN 1 SABARU PALANGKA RAYA
}

\section{Scramble Learning Model using Puppet Heroes Media to Increase Social Sciences Learning Result Participants of V-A Class at SDN 1 Sabaru Palangka Raya}

\author{
*Rita Rahmaniati, Bulkani, \& Fitri Pujianti \\ Elementary Teacher Education Study Program, Universitas Muhammadiyah Palangkaraya, RTA Milono St. Km.1,5 \\ Palangka Raya, Indonesia \\ *e-mail : rahmaniatirita@yahoo.co.id
}

\begin{abstract}
ABSTRAK
Penelitian ini bertujuan untuk mengetahui: (1) Aktivitas belajar peserta didik dalam pembelajaran IPS pada penerapan model pembelajaran scramble dengan menggunakan media wayang pahlawan (Puppet Heroes), dan (2) Peningkatan hasil belajar IPS setelah penerapan model pembelajaran scramble dengan menggunakan media wayang pahlawan. Jenis penelitian ini adalah Penelitian Tindakan Kelas (PTK). Subjek penelitian adalah peserta didik kelas V-A di SDN 1 Sabaru Palangkaraya yang berjumlah 23 orang peserta didik yang sekaligus dijadikan sampel penelitian. Pengumpulan data menggunakan observasi dan tes, sedangkan untuk teknik analisis data menggunakan teknik analisis ketuntasan klasikal dan individual. Dari hasil penelitian disimpulkan bahwa: (1) Peserta didik lebih aktif dalam pembelajaran IPS pada penerapan model pembelajaran scramble dengan menggunakan media wayang pahlawan, Peserta didik berperan aktif, termotivasi, saling bekerjasama dengan meningkatkan kosentrasi dan kecepatan berpikir selama proses pembelajaran pada siklus I. Adapun hasil pengamatan aktivitas guru pada proses pembelajaran yang dilakukan oleh pengamat I dan pengamat II selama proses pembelajaran ilmu pengetahuan sosial (IPS) pada siklus I rata-rata aspek aktivitas guru yaitu 3,63 dengan kriteria sangat baik dan rata-rata aspek aktivitas peserta didik yaitu 3,37 dengan kriteria baik, dan (2) Ada peningkatan hasil belajar belajar IPS peserta didik setelah penerapan model pembelajaran scramble dengan menggunakan media wayang pahlawan. Hal ini ditunjukkan dengan hasil belajar yang dilihat melalui skor rata-rata kelas pada siklus I yaitu 80,21 dengan kriteria tercapai dan memenuhi KKM 70, mencapai persentase ketuntasan belajar peserta didik secara klasikal yaitu 100\%, dengan ketuntasan klasikal $85 \%$.
\end{abstract}

Kata kunci: Hasil Belajar IPS, Model Pembelajaran Scramble, Media Wayang Pahlawan

\begin{abstract}
This study aims to find out: (1) Student learning activities in IPS (Social Sciences) learning on the application of scramble learning model using puppet hero media (Puppet Heroes), and (2) Improvement of IPS learning outcomes after application of learning model of scramble using media of wayang heroes. This type of research is Classroom Action Research (PTK). The subjects of the study were V-A students at SDN 1 Sabaru Palangkaraya which consisted of 23 students who were also used as research samples. Data collection using observation and test, while for data analysis technique using analysis technique of classical and individual completeness. From the research result, it can be concluded that: (1) learners are more active in IPS learning on the application of scramble learning model by using puppet hero media, students play an active role, motivated, cooperate with increasing concentration and speed of thinking during learning process in cycle I. the observation of teacher activity on the learning process conducted by observer I and observer II during social science learning process (IPS) in cycle I average aspects of teacher activity is 3.63 with very good criteria and the average aspects of the activities of learners that is 3.37 with good criteria, and (2) There is an increase in learning outcomes of IPS learners after the application of the model of learning scramble using the media of wayang heroes. This is indicated by the results of learning seen through the average scores of classes in the first cycle is 80.21 with the criteria achieved and meet the KKM 70, reaching the percentage of learning mastery learners classically that is $100 \%$, with $85 \%$ classical completeness.
\end{abstract}

Keywords: Social Sciences Learning Results, Scramble learning model, Puppet Heroes Media 


\section{PENDAHULUAN}

IImu pengetahuan sosial (IPS) adalah sekelompok disiplin akademis yang mempelajari aspek-aspek yang berhubungan dengan manusia dan lingkungan sosialnya. Menurut Jarolimek (Susanto, 2013:141) "Pendidikan IPS berhubungan erat dengan pengetahuan, keterampilan, sikap dan nilai-nilai yang memungkinkan peserta didik berperan serta dalam kelompok masyarakat di mana dia tinggal". Peserta didik diarahkan untuk dapat menjadi warga negara Indonesia yang demokratis, dan bertanggung jawab, serta warga dunia yang cinta damai. Menurut Hadi (Susanto, 2013), bahwa:

"Ada empat tujuan pendidikan IPS, yaitu: knowledge, skill, attitude, dan value. Pertama, knowledge, sebagai tujuan utama dari pendidikan IPS yaitu membantu peserta didik sendiri untuk mengenal diri mereka sendiri dan lingkungannya, dan mencakup geografi, sejarah, politik, ekonomi, dan sosiologi psikologi. Kedua skill, yang mencakup keterampilan berpikir (thinking skills). Ketiga attitudes, yang terdiri atas tingkah laku berpikir (intellectual behavior). Keempat value, yaitu nilai yang terkandung didalam masyarakat yang diperoleh dari lingkungan masyarakat maupun lembaga pemerintah, termasuk didalamnya nilai kepercayaan, nilai ekonomi, pergaulan antarbangsa, dan ketaatan kepada pemerintah dan hukum."

Untuk mencapai tujuan ilmu pengetahuan sosial (IPS) tersebut, ada peran seorang guru selaku pendidik bagi peserta didik agar tujuan pembelajaran yang diharapkan dapat tercapai. Menurut Mudlofir (2013) "Guru adalah pendidik profesional dengan tugas utama mendidik, mengajar, membimbing, mengarahkan, melatih, menilai dan mengevaluasi peserta didik pada jalur pendidikan formal". Tugas guru adalah menyampaikan materi pelajaran kepada peserta didik melalui interaksi komunikasi dalam proses pembelajaran, seorang guru hendaknya dapat menciptakan kondisi dan situasi pembelajaran yang memungkinkan peserta didik aktif membentuk, menemukan, dan mengembangkan pengetahuannya. Kemudian peserta didik dapat membentuk makna dari bahan-bahan pelajaran melalui suatu proses belajar dan mengontruksinya dalam ingatan yang sewaktu-waktu dapat diproses dan dikembangkan lebih lanjut. Menurut Trianto (2014) "Cara mengajar guru yang baik merupakan kunci dan prasarat bagi peserta didik untuk dapat belajar dengan baik". Namun, rendahnya hasil belajar ilmu pengetahuan sosial (IPS) masih menjadi masalah yang begitu umum di dunia pendidikan, hal ini menjadi alasan kuat perlunya perhatian dan penanganan serius terhadap proses pembelajaran ilmu pengetahuan sosial (IPS).

Rendahnya hasil belajar belajar ilmu pengetahuan sosial (IPS) peserta didik tersebut, tentu banyak faktor yang menyebabkannya, misalnya tentang penerapan metode pembelajaran ilmu pengetahuan sosial (IPS) yang masih terpusat pada guru (teacher oriented), sementara peserta didik cenderung pasif. Penerapan model pembelajaran yang masih konvensional, pengajaran yang demikian ini menyebabkan peserta didik kurang berpartisipasi aktif dalam pembelajaran, sehingga dikhawatirkan peserta didik tidak dapat meningkatkan aktivitas belajar ilmu pengetahuan sosial (IPS) untuk meningkatkan pengembangan kemampuannya. Permasalahan ini masih banyak kita temukan di sekolah-sekolah dasar khususnya di SDN 1 Sabaru Palangkaraya. 
Berdasarkan observasi awal pada tanggal 1-2 dan 8-9 November 2016 di kelas V-A SDN 1 Sabaru Palangka Raya, dalam proses pembelajaran IImu Pengetahuan Sosial (IPS) cenderung masih berpusat pada guru. Guru kurang bervariasi dalam menggunakan model pembelajaran dan guru melakukan proses pembelajaran hanya menjelaskan dari papan tulis, buku paket dan LKS. $\mathrm{Hal}$ ini berpengaruh pada hasil belajar IPS. Hal tersebut terlihat dari hasil belajar IPS kelas $\mathrm{V}$ sebagian besar masih mendapatkan hasil belajar di bawah KKM yang telah ditentukan pada mata pelajaran ilmu pengetahuan sosial (IPS) yaitu 7,00. Dari 23 orang peserta didik hanya 8 peserta didik (35\%) yang tuntas di atas KKM, sedangkan 15 peserta didik (65\%) belum tuntas dari KKM.

Berdasarkan temuan ini, maka perlu dilakukan perbaikan pembelajaran untuk meningkatkan hasil belajar peserta didik. Penggunaan model pembelajaran yang dipadukan dengan media yang bervariasi merupakan salah satu alternatif perbaikan pembelajaran sehingga pembelajaran mengarah pada student center.

Salah satu model pembelajaran yang mampu menumbuhkan motivasi, dan menambah rasa percaya diri dalam proses pembelajaran adalah model pembelajaran scramble. Scramble dianggap sebagai model yang tepat dalam pembelajaran IPS.

Menurut Huda (2013), "Scramble model pembelajaran yang dapat meningkatkan kosentrasi dan kecepatan berpikir peserta didik, mereka tidak hanya diminta untuk menjawab soal, tetapi juga menerka dengan cepat jawaban soal yang tersedia namun masih dalam kondisi acak". Menurut Huda (2013) kelebihan model pembelajaran scramble adalah "Melatih peserta didik untuk berpikir cepat dan tepat, mendorong peserta didik untuk belajar mengerjakan soal dengan jawaban acak, dan melatih kedisiplinan peserta didik".

Menurut Jajang Suryana (Aizid, 2012), "Wayang bisa mengandung makna gambar, boneka tiruan manusia yang terbuat dari kulit, kardus, seng, mungkin kaca kerat (fibre-glass) bahan dwi mantra lainnya dan dari kayu pipih maupun bahan torak tiga dimensi". Wayang dapat dikembangkan atau diinovasikan sebagai media pembelajaran yang dapat digunakan guru. Wayang adalah media yang tampilannya dapat diamati dari satu arah pandang saja dan termasuk ke dalam media pembelajaran dua dimensi (2D).

Wayang pahlawan (puppet heroes) adalah gambar dalam bentuk manusia dan tokoh-tokoh pahlawan Indonesia yang menjadi karakternya, yang dihubungkan dengan sebuah tongkat sebagai pegangan atau penggendali geraknya serta dilengkapi sebuah panggung yang dimodifikasi sedemikian rupa sesuai dengan suasana mempersiapkan dan mempertahankan kemerdekaan.

Tujuan dari penelitian ini adalah untuk mengetahui aktivitas belajar dan hasil belajar IPS peserta didik kelas V-A di SDN 1 Sabaru Palagka Raya pada penerapan model pembelajaran sramble menggunakan media wayang pahlawan.

\section{METODOLOGI}

Penelitian dilaksanakan menurut pendekatan kualitatif dengan menggunakan metode Penelitian Tindakan Kelas (PTK). Penelitian Tindakan ini dirancang 2 siklus. Setiap siklus terdiri atas 2 Jam pelajaran, yang dalam pelaksanaannya mencakup empat langkah dalam satu siklus, yaitu : 1) 
penyusunan rencana, 2) pelaksanaan tindakan, 3) observasi tindakan, 4) refleksi atas tindakan yang dilaksanakan. Alur pelaksanaan PTK model Kemmis dan Taggart dapat dilihat pada Gambar 1. Peneliti berperan sebagai perencana, pelaksana tindakan, pengamat, reflektor dan sebagai pelapor hasil penelitian. Sebagai subjek pemberi tindakan, peneiti bertindak sebagai pengajar atau guru model yang bertugas yang membuat rancangan pelaksanaan pembelajaran (RPP) sekaligus menyampaikan bahan ajar selama pembelajaran. Di samping itu, peneliti juga mengumpulkan dan menganalisis data serta sebagai pelapor hasil penelitian.

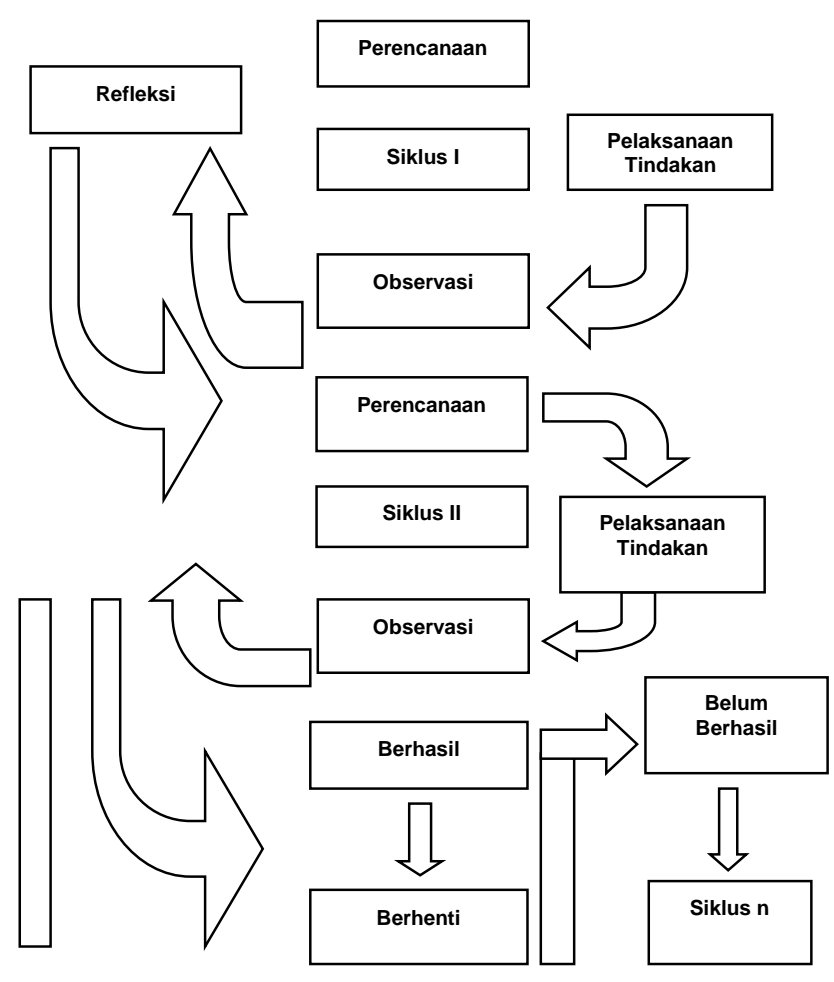

Gambar 1: Siklus Penelitian Tindakan Kelas (PTK) Sumber: Kemmis dan McTaggart (Arikunto, 2006)

Teknik penelitian dalam penelitian ini melalui tes dan observasi. Observasi dalam penelitian ini adalah observasi langsung yaitu pengamat melihat dan mengamati secara langsung kemudian mencatat perilaku dan kejadian yang terjadi pada keadaan yang sebenarnya saat pembelajaran berlangsung dengan menerapkan model pembelajaran scramble dengan menggunakan media wayang pahlawan (puppet heroes) dapat meningkatkan hasil belajar siswa. Adapun tes dalam penelitian ini menggunakan pretest dan post test yaitu dalam bentuk soal pilihan ganda (PG).

Data dalam penelitian ini dianalisis secara kualitatif dan kuantitatif. Data kualitatif diperoleh dari aktivitas guru dan peserta didik dalam pembelajaran yang dikelola guru dengan penerapan model pembelajaran scramble dengan menggunakan media wayang pahlawan (puppet heroes). Sedangkan data kuantitatif berasal dari pretest yang dilakukan diawal pertemuan ada posttest yang dilakukan diakhir pembelajaran dengan rumus:

$$
M=\frac{\sum N}{\mathrm{~N}}
$$

Keterangan:

$M \quad=$ Nilai rata-rata kelas

$\sum \mathrm{N} \quad=$ Total nilai yang diperoleh peserta didik

$\mathrm{N} \quad=$ Jumlah peserta didik

Persentase Ketuntasan belajar peserta didik secara klasikal dengan rumus:

$$
\text { TB }=\frac{\sum \mathrm{s} \geq 70 \times 100 \%}{N}
$$

Keterangan:

TB = Ketuntasan belajar klasikal, minimal $85 \%$ $\Sigma \mathrm{s} \geq 70=$ Jumlah peserta didik yang mendapatkan nilai $\geq 70$

$$
\begin{array}{ll}
\mathrm{N} & =\text { Banyak peserta didik } \\
100 \% & =\text { Bilangan tetap }
\end{array}
$$




\section{HASIL DAN PEMBAHASAN}

Berdasarkan analisis data yang dilakukan terhadap aktivitas peserta didik pada siklus I yang memperoleh nilai rata-rata 3,37 dengan kriteria baik. Peserta didik yang awalnya kurang aktif selama proses pembelajaran berlangsung, namun pada saat peneliti menerapkan model pembelajaran scramble, peserta didik lebih aktif dan saling bekerjasama dalam meningkatkan kosentrasi dan kecepatan berpikirnya dalam mengerjakan LKPD secara berkelompok, sehingga setiap peserta didik terlibat aktif dan mampu meningkatkan kosentrasi serta kecepatan berpikirnya dalam proses pembelajaran. Karena model pembelajaran scramble adalah model pembelajaran yang dapat meningkatkan kosentrasi dan kecepatan berpikir peserta didik, mereka tidak hanya diminta untuk menjawab soal, tetapi juga menerka dengan cepat jawaban soal yang tersedia namun masih dalam kondisi acak. Salah satu kelebihan dari model pembelajaran scramble adalah semua peserta didik dapat terlibat aktif. Peserta didik yang awalnya kurang tertarik selama proses pembelajaran berlangsung, namun pada saat peneliti menggunakan media wayang pahlawan (puppet heroes), peserta didik termotivasi dan tertarik selama proses pembelajaran. Karena media wayang pahlawan (puppet heroes) memiliki kelebihan yaitu dapat menarik minat peserta didik dalam pembelajaran dan dapat membuat suasana kelas menjadi gembira.

Hasil belajar peserta didik mengalami peningkatan, hal tersebut dapat dilihat dari data hasil belajar peserta didik yang diperoleh dari pre test dan post test siklus I. Pada tes awal (pre test), hasil belajar peserta didik memperoleh skor rata-rata 59,56 dengan ketuntasan klasikal $43,47 \%$ juga masih jauh dari kriteria ketuntasan klasikal $85 \%$. Kemudian pada siklus I saat diberikan post test hasil belajar peserta didik memperoleh skor ratarata 80,21 dan telah mencapai KKM 70, dengan ketuntasan klasikal $100 \%$ yang telah memenuhi kriteria ketuntasan klasikal 85\%. Dari hasil penelitian ini, penerapan model pembelajaran scramble dengan menggunakan media wayang pahlawan (puppet heroes) dalam pembelajaran ilmu pengetahuan sosial (IPS) pada materi upaya mempersiapkan dan mempertahankan kemerdekaan mampu meningkatkan hasil belajar peserta didik.

Berikut ini adalah diagram yang menunjukkan persentase peningkatan hasil belajar ilmu pengetahuan sosial (IPS) pada saat pra tindakan dan pelaksanaan tindakan siklus I.

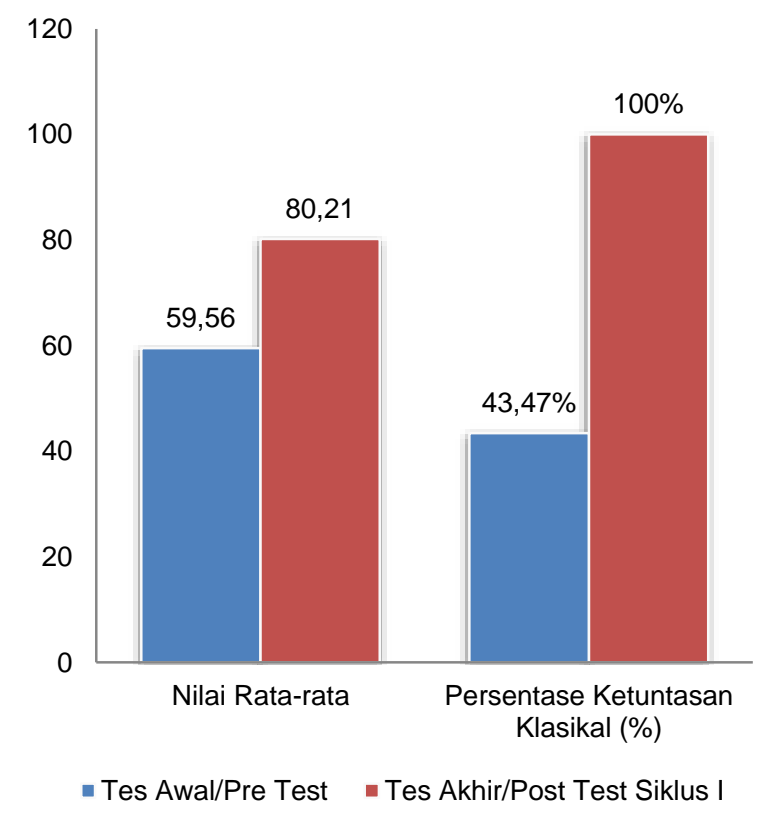

Gambar 2. Diagram Grafik Peningkatan Hasil Belajar Peserta Didik

Peningkatan aktivitas dan hasil belajar peserta didik V A SDN 1 Sabaru Palangkaraya diduga karena penggunaan model pembelajaran scramble 
yang mampu mendorong peserta didik mengembangkan potensi dalam dirinya. Hal ini senada dengan pernyataan Huda (2013) model pembelajaran scramble memiliki kelebihan yaitu "1) melatih peserta didik untuk berpikir cepat dan tepat; 2) mendorong peserta didik untuk belajar mengerjakan soal dengan jawaban acak; 3) melatih kedisiplinan peserta didik". Selain itu penggunaan media wayang pahlawan (puppet heroes) dalam proses pembelajaran ilmu pengetahuan sosial (IPS) mampu meningkatkan aktivitas belajar peserta didik hal ini karena media wayang pahlawan (puppet heroes) memiliki kelebihan yaitu :1) dapat menarik minat peserta didik dalam pembelajaran 2) efisien terhadap tempat, biaya dan persiapan karna media dibuat oleh guru sendiri 3) dapat membuat suasana kelas gembira 4) dapat mengembangkan suatu materi atau peristiwa secara estetis.

\section{KESIMPULAN}

Dari apa yang telah diuraikan di atas, dapat dikemukakan beberapa kesimpulan sebagai berikut:

1. Peserta didik lebih aktif dalam pembelajaran IPS pada penerapan model pembelajaran scramble dengan menggunakan media wayang pahlawan (puppet heroes) di kelas V-A SDN 1 Sabaru Palangkaraya tahun pelajaran 2016/2017. Peserta didik berperan aktif, termotivasi, saling bekerjasama dengan meningkatkan kosentrasi dan kecepatan berpikir selama proses pembelajaran pada siklus I. Adapun hasil pengamatan aktivitas guru pada proses pembelajaran yang dilakukan oleh pengamat I dan pengamat II selama proses pembelajaran ilmu pengetahuan sosial (IPS) pada siklus I rata-rata aspek aktivitas guru yaitu 3,63 dengan kriteria sangat baik dan ratarata aspek aktivitas peserta didik yaitu 3,37 dengan kriteria baik.

2. Ada peningkatan hasil belajar belajar IPS peserta didik kelas V-A di SDN 1 Sabaru Palangkaraya tahun pelajaran 2016/2017 setelah penerapan model pembelajaran scramble dengan menggunakan media wayang pahlawan (puppet heroes). Hal ini ditunjukkan dengan hasil belajar yang dilihat melalui skor rata-rata kelas pada siklus I yaitu 80,21 dan persentase ketuntasan belajar peserta didik secara klasikal yaitu $100 \%$, dari kriteria yang telah ditentukan yaitu untuk KKM adalah 70 dan kriteria ketuntasan secara klasikal adalah $85 \%$. Dengan ini maka dapat disimpulkan bahwa ada peningkatan hasil belajar IPS peserta didik setelah penerapan model pembelajaran scramble dengan menggunakan media wayang pahlawan (puppet heroes).

\section{DAFTAR PUSTAKA}

Arikunto, Suharsimi. (2007). Dasar-dasar Evaluasi Pendidikan. Jakarta: Bumi Aksara.

Arsyad, A. (2013). Media Pendidikan.Bandung: PT Citra Aditya.

Asyhar, Rayandra. (2012). Kreatif Mengembangkan Media Pembelajaran. Jakarta: Referensi Jakarta.

Huda, Miftahul. (2013). Model-model Pengajaran dan Pembelajaran. Yogyakarta: Pustaka Pelajar.

Narbuko, C., \& Abu Achmadi. (2001). Metodologi Penelitian. Jakarta: PT Bumi Aksara. 
Santyasa. (2007). Metodologi Penelitian Tindakan Kelas. Singaraja: Universitas Pendidikan Ganesa.

Somadayo, Samsu. (2013). Penelitian Tindakan Kelas. Yagyakarta: Graha IImu.

Sudjana, Nana. (2012). Penilaian Hasil Proses Belajar Mengajar. Bandung: PT Remaja Rosdakarya.

Sukardi, M. (2011). Evaluasi Pendidikan Prinsip dan Operasionalnya. Jakarta: PT. Bumi Aksara. 